\title{
Kiégés a magyar fogorvosok körében
}

\author{
Szalai Eszter dr. ${ }^{1}$ - Hallgató Júlia dr. ${ }^{1}$ \\ Kunovszki Péter ${ }^{2}$. Tóth Zsuzsanna dr. ${ }^{1}$ \\ ISemmelweis Egyetem, Fogorvostudományi Kar, Konzerváló Fogászati Klinika, Budapest \\ ${ }^{2}$ Budapesti Múszaki és Gazdaságtudományi Egyetem, Kémiai és Környezeti Folyamatmérnöki Tanszék, Budapest
}

Bevezetés: A kiégés jelensége fokozottan érinti az egészségügyi dolgozókat, a nagyfokú stressz, a folyamatos fizikai és emocionális megterhelés miatt. A kiégés mérését fogorvosok körében végeztük, mivel Magyarországon még nem készült csak fogorvosokat mérő keresztmetszeti vizsgálat.

Célkitüzés: Elsődleges célunk a fogorvosi kiégés előfordulásának, súlyosságának mérése, a rizikófaktorok kiszűrése volt. Másodlagos célul a kiégés veszélyére való figyelem felkeltését tűztük ki az érintett csoportban.

Módszer: Az adatgyújtés a 'Maslach Burnout Inventory - Human Services Survey' 22 tételes magyar, validált változatával történt online formában.

Eredmények: Online kérdőívünket 407 fogorvos töltötte ki. A következő eredményeket kaptuk: az emocionális kimerülés esetében a válaszadók 20\%-a (81 fó) tartozik a magas kategóriába, a cinizmus dimenziójának esetében a válaszadók 17,5\%-át (70 fó) jellemzi a magas pontszám. A teljesítményvesztés magas dimenziója a minta 75\%-ában (302 fó) volt igazolható. Szignifikáns $(\mathrm{p} \leq 0,05)$ védőfaktornak találtuk a harmonikus kollegiális viszonyt, a hobbi meglétét, a 2-4 óra napi munkát, a támogató otthoni és munkahelyi légkört, az egészségi probléma és a saját vállalkozás hiányát. Szignifikáns negatív eltérést 6-10 éve dolgozó férfiak körében találtunk.

Következtetés: Az eredmények felhívják a figyelmet a legfontosabb protektív tényezőkre, melyek segítségével csökkenthető a kiégés mértéke.

Orv Hetil. $2021 ; 162(11): 419-424$

Kulcsszavak: burnout, kiégés, fogorvos, Maslach, MBI

\section{Burnout among Hungarian dentists}

Introduction: Burnout has an increased impact on healthcare workers due to severe stress, constant physical and emotional strain. Burnout was measured among dentists, as no such cross-sectional study has been made in Hungary. Objective: Our primary goal was to measure the incidence and severity of dental burnout and to screen for the risk factors. Our secondary goal was to raise awareness of the risk of burnout in the affected group.

Method: Data collection was performed online with the 22-item Hungarian validated version of Maslach Burnout Inventory - Human Services Survey.

Results: 407 dentists completed our online questionnaire. The following results were obtained: in the case of emotional exhaustion, $20 \%$ of the respondents belong to the high category, in the cynicism dimension, $17.5 \%$ of the respondents have high scores. The high dimension of performance loss is typical in $75 \%$ of the sample. We found that harmonious collegial relationships, the existence of a hobby, 2-4 hours of daily work, a supportive home and work atmosphere, the lack of health problems and self-employment are significant $(p \leq 0.05)$ protective factors. Significant negative differences were found among men who had been working for 6-10 years.

Conclusion: The results draw attention to the most important protective factors that can help reduce the rate of burnout.

Keywords: burnout, dentist, Maslach, MBI

Szalai E, Hallgató J, Kunovszki P, Tóth Zs. [Burnout among Hungarian dentists]. Orv Hetil. 2021; 162(11): 419424 .

(Beérkezett: 2020. július 30.; elfogadva: 2020. október 8.) 


\section{Rövidítések}

$\mathrm{DP}=$ deperszonalizáció; $\mathrm{EE}=($ emotional exhaustion $)$ érzelmi kimerültség; $\mathrm{MBI}=($ Maslach Burnout Inventory) Maslach Kiégés Leltár; PA = (personal accomplishment) személyes hatékonyság

A kiégésszindróma fogalmát az 1970-es években kezdték el használni pszichológusok. A tünetegyüttes hosszú távú fokozott érzelmi megterhelés, kedvezőtlen stresszhatások következtében létrejövő fizikai, érzelmi, mentális kimerülés [1].

Számos kutatás indult e jelenség felmérésére az egészségügyi dolgozók körében, de célzottan, csak a magyar fogorvostársadalmat érintő adatokat eddig még nem közöltek. Ez adta a kutatás alapötletét. Van-e okunk aggodalomra, számolnunk kell-e azzal a lehetőséggel, hogy a fogorvosokat esetleg fokozottabban is veszélyezteti maga a kiégés jelensége, illetve ha igen, milyen módon vehető ez észre? Mit tehetünk, amennyiben - a legtöbbször öndiagnózis útján - diagnózishoz vezetnek a tünetek?

Gyakori eset, hogy a kiégés újratermeli önmagát azáltal, hogy a szindrómához kapcsolódó stressz, problémák leküzdéséhez inadekvát stratégiákat választ az egyén [2].

A kiégésszindróma szinte minden foglalkozásnál előfordulhat. Különösen gyakori azonban a humánszolgáltatások, az egészségügy szférájában. A segítők gyakori nagy lelkesedése ellenére az alacsony jövedelem, a hoszszú munkaidő, az extra igénybevétel melletti nagy felelősség, ugyanakkor az elégtelen intézményi támogatás, az adminisztratív terhek, a karrier, az előrejutási lehetôségek határai, az alacsony megbecsülés érzése mind az ellátottak, mind pedig a társadalom részéról nagyban hozzájárulnak e nemkívánatos jelenség kialakulásához $[3]$.

A fogorvosok körében jelen vannak mind a túlzott, sokszor irreális elvárások (akár a vezetőség, akár a kollégák vagy a páciensek részéről), mind a nagy felelősséggel járó kezelések miatti állandósult stressz. Sokszor nem jut elegendő idő a pihenésre, kikapcsolódásra, a testi és szellemi rehabilitációra az állandó időnyomás miatt. A munka sokszor együtt jár a napjainkban egyre gyakoribb kártérítési perektől, a büntetőjogi felelősségre vonástól való félelemmel, amelyek együtt odavezethetnek, hogy végül a szindróma pszichoszomatikus tüneteket is produkál, és az orvos egészségkárosodásával is számolnunk kell; a kiégés ugyanakkor növeli a lehetséges hibák számát [4]. Bár minden szakmában fennáll a kiégés veszélye, a fogorvosok különösen nagy kockázatnak vannak kitéve, nemcsak a mentális nehézségek miatt, hanem fizikálisan is igen megterhelő a feladatuk. A fogorvosok egyre nagyobb figyelmet fordítanak az ergonomikus munkavégzésre, felismerve ennek fontosságát, de a berögzült rossz szokásokon nehéz felülkerekedni. Továbbá financiálisan sem olyan egyszerü a fogorvosok többségének helyzete, legyen szó alap- vagy magánellátásról. A drága anyagok, eszközök, munkaerő árának megtermelése a legtöbbször nem áll arányban a szolgáltatás anyagi megbecsültségével. Ha felismerjük az intő jeleket, ha tudjuk, mire is kell odafigyelnünk saját és kollégáink viselkedését illetően, segíthetünk a kiégés megelőzésében vagy kezelésében.

A következő tünetek segíthetnek a kiégés felismerésében:

- Testi tünetek: feszültség, fáradtság, fejfájás, testsúlyváltozás, alvászavarok, pszichoszomatikus megbetegedések (például magas vérnyomás, táplálkozási zavarok, fekélybetegség).

- Pszichés tünetek: ingerlékenység, cinizmus, az emberi kapcsolatok minőségének megromlása, a munkahelyhez, kollégákhoz való negatív viszonyulás, serkentőés nyugtatószerek fokozott használata, betegállományba vonulás, a teljesítőképesség csökkenése, az elköteleződés csökkenése, indokolatlan szakmai önértékelési problémák, labilissá válás, szorongás, depreszszió, rögeszmék megjelenése, az elszemélytelenedés érzése [5].

A kiégés következményei: a munkaminőség és a teljesítmény csökkenése, a gyakori hiányzás, a munkahelyek sűrű váltogatása, vandalizmus vagy tolvajlás, alkoholvagy egyéb függőség, például drogfüggőség, pszichoszomatikus panaszok kialakulása, betegségbe menekülés, múhibák, szaporodó, családon és baráti körön belüli vagy munkahelyi konfliktusok [6].

\section{A vizsgálat célja}

Célunk a kiégés fokának mérése, különböző komponenseinek (emocionális kimerülés, cinizmus, teljesítménycsökkenés) meghatározása volt. Továbbá kerestük a különböző rizikófaktorok közül a leginkább befolyásolókat (a munkaidő hossza, a munkahelyi környezet, a személyes kapcsolatok, a hobbi hiánya stb.). Mindezek mellett a demográfiai adatok gyújtésével átfogóbb képet kívántunk nyújtani.

\section{Módszer}

2013 nyarán online kérdőívet küldtünk ki 1867 magyar fogorvos részére, melynek kitöltése önkéntes és anonim módon történt a rendelkezésre álló nyolc hét alatt. A mintavételhez a résztvevők előzetesen kikért hozzájárulása után a Semmelweis Egyetem Fogorvostudományi Karának Szak- és Továbbképzési Titkársága biztosította az e-mail-címeket. A teszt első részében a lehetséges rizikófaktorokra kérdeztünk rá, a második részben a Maslach Kiégés Leltár (Maslach Burnout Inventory - MBI) kapott helyet [7], legvégül demográfiai adatokat gyüjtöttünk. A kiégés mérésére különféle kérdőívek léteznek, de a szakirodalomban az MBI [7] a leginkább használt és elfogadott. Ennek a kérdóívnek többféle változata ismert. A kiértékelés az adott dimenziókra vonatkozó kérdések összpontszáma alapján történik, amit egy háromfokozatú skálára soroltak be, így az értékek alacsony, 
közepes és magas kategóriába kerülnek. Mi a humánszolgáltatási szektorban dolgozók számára készített kérdőívet használtuk, annak is a validált változatát, amely Ádám és Mészáros nevéhez köthető [8]. Az MBI rövid állításokat tartalmaz, amelyeknél 0-tól (soha) 6-ig (minden nap) terjedő skálán kell jelölni az érzés gyakoriságát. Az MBI három dimenziót mér: a személy érzelmi kimerültségét (EE), deperszonalizációját (DP) és a személyes hatékonyságot (PA). Emocionális kimerültségen azt értjük, ha valaki már a munka gondolatától is fáradt, reggeltől estig, éjjel és nappal krónikusan kimerült. Jellemzői: alvászavarok, álmatlanság, nagyobb hajlam a megbetegedésre, diffúz testi panaszok és csökkent szexuális potencia. A DP cinikus beállítódást jelent a kollégákkal, negatív érzelmeket a betegekkel, ügyfelekkel, tanítványokkal és diákokkal szemben, bűntudatot, a társadalmi kontaktusok beszúküulését, hárító magatartást, a munkának a legszükségesebbre való korlátozását. Ugyancsak fontos aspektus a teljesítménnyel való elégedetlenség, a csökkent teljesítőképesség, valamint a sikertelenség és tehetetlenség megélése, hiányzó elismerés, hiányos visszajelzés, elégtelenségérzés, krónikus túlterheltség [2].

Az általunk vizsgált rizikófaktorok a következők voltak: fóállású vagy mellékállású a fogorvos, esetleg mindkettővel rendelkezik. Rákérdeztünk a munkával eltöltött időre és a szabadidőre, a munkával eltöltött évek számára, az egészségi állapotra, a magánélet minőségére.

A munkahelyi légkör szerepére különösen kíváncsiak voltunk, ezért több kérdéssel is mértük, ezt tartjuk a kérdőív erősségének.

- Hogyan értékelné a munkatársaihoz füződő kapcsolatát?

- Milyennek látja a felettesével (feletteseivel) való kapcsolatát?

- Szakmailag megbecsülik Önt a munkahelyén?

- Emberileg, erkölcsileg megbecsülik Önt a munkahelyén?

- Van-e beleszólása az Önt érintő szakmai kérdésekbe? Kérdőívünk korlátai a következők: nem vizsgáltuk, hogy alap- vagy magánellátó a válaszadó, mert hazánkban olyan nagy az átfedés e két terület között, hogy valószínúleg téves információkra jutottunk volna. A vállalkozói létre rákérdeztünk, amely feltételezésünk szerint extra igénybevételt ró a fogorvosra. Továbbá nem arra helyeztük a hangsúlyt, hogy a munkavállaló egyedül vagy egy nagyobb csapat részeként dolgozik, hanem a munkakörnyezetet, a munkatársakkal létesített kapcsolatok minőségét vizsgáltuk, mert álláspontunk szerint ez lehet az elsődleges rizikófaktor.

Az adatokat a Statistica program (Version 11; StatSoft, Inc., Tulsa, OK, Amerikai Egyesült Államok) segítségével értékeltük ki, a szignifikanciaszintet 5\%-on határoztuk meg $(p \leq 0,05)$. A számítás ordinális multinomiális eloszláson alapuló logisztikus regresszió (logistic regression for ordinal multinomially distributed responses), a próbák pedig Wald-típusúak.

\section{Eredmények}

A megszólított 1869 fogorvos közül 407, a megkérdezettek 21,7\%-a töltötte ki online kérdőívünket, köztük 234 nő (57\%) volt és 173 (43\%) férfi, átlagéletkoruk 44 év. Az alacsony részvételi arány ellenére a véletlen mintavétel, a speciális kiválasztási szempont hiánya, valamint a minta demográfiai jellemzői (kor, nem, lakhely, családi állapot) hasonlóak az alapsokaságéihoz, ez biztosítja a minta reprezentativitását. A válaszadók több mint fele családban vagy élettársi kapcsolatban él (1. ábra), és átlagosan 1,3 gyermeket nevel.

A kitöltők 57\%-a jelölte meg munkahelyének Budapestet, 37\%-uk városban dolgozik, és csak 6\%-uk faluban (2. ábra). A válaszadók 95\%-ának van fóállása, 69\%-uk rendelkezik saját vállalkozással is.

A következő eredményeket kaptuk az emocionális kimerülés esetében: a válaszadók 20\%-a ( 81 fó) tartozik a magas kategóriába, a cinizmus dimenziója esetében a válaszadók 17,5\%-át (70 fő) jellemzi a magas pontszám. A teljesítményvesztés magas dimenziója a minta 75\%-ára (302 fö) jellemző.

A cinizmus terén a férfiak szignifikánsan $(\mathrm{p} \leq 0,05)$ rosszabb eredményeket mutattak, mint a nók (1. táblázat). Szignifikáns védőfaktornak találtuk a harmonikus kollegiális viszonyt és a hobbi meglétét. Ezek közül is a jó munkahelyi légkör bizonyult a leginkább meghatározónak a DP megelőzése szempontjából.

Az érzelmi kimerülés vonatkozásában szignifikáns védőfaktornak találtuk a támogató otthoni és munkahelyi

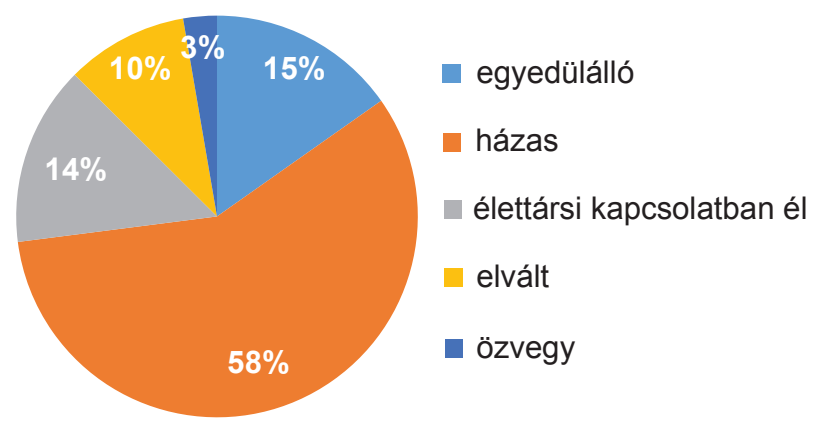

1. ábra | A válaszadó magyar fogorvosok családi állapota

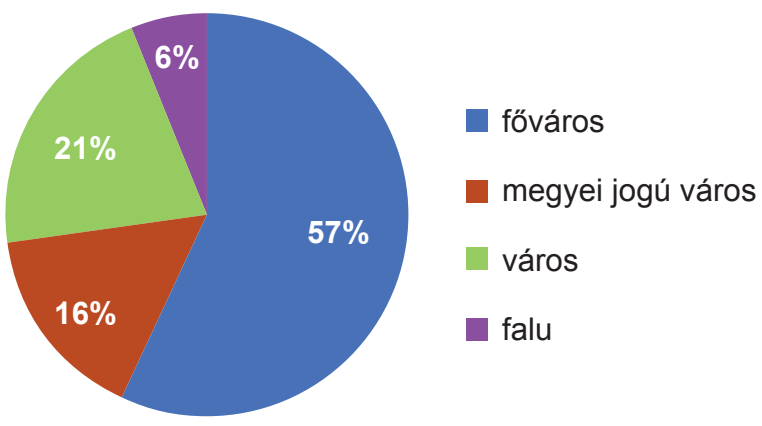

2. ábra $\quad$ A válaszadó magyar fogorvosok lakhelye a település jellege szerint 
1. táblázat

A cinizmust befolyásoló tényezők, szignifikáns eltérés a kiemel teknél

\begin{tabular}{lllll}
\hline Cinizmus & Válasz & Becslés & $\begin{array}{l}\text { Standard } \\
\text { hiba }\end{array}$ & $\mathrm{p}$ \\
\hline Neme & Férfi & $-0,294$ & 0,106 & 0,005 \\
Hány éve tart ez így? & $0-1$ & $-0,626$ & 0,305 & 0,040 \\
Hány éve tart ez így? & $1-2$ & $-0,246$ & 0,321 & 0,443 \\
Hány éve tart ez így? & $3-5$ & 0,473 & 0,278 & 0,088 \\
Hány éve tart ez így? & $5-8$ & $-0,236$ & 0,289 & 0,413 \\
Hány éve tart ez így? & $9-10$ & $-0,412$ & 0,405 & 0,308 \\
Hány éve tart ez így? & $11-15$ & 0,187 & 0,253 & 0,459 \\
Hány éve tart ez így? & $21-25$ & 0,176 & 0,371 & 0,635 \\
Hány éve tart ez így? & $25-30$ & 0,276 & 0,239 & 0,249 \\
Van hobbija? & Igen & 0,400 & 0,121 & 0,001 \\
$\begin{array}{l}\text { Otthon vagy munkahelyen } \\
\text { kívüli baráti társaságban meg } \\
\text { tudja beszélni a munkával } \\
\text { kapcsolatos érzéseit, élményeit? }\end{array}$ & Igen & 0,460 & 0,136 & 0,000 \\
\hline & & & & \\
\hline
\end{tabular}

2. táblázat Az érzelmi kimerülést befolyásoló tényezők, szignifikáns eltérés a kiemelteknél

\begin{tabular}{|c|c|c|c|c|}
\hline Érzelmi kimerülés & Válasz & Becslés & $\begin{array}{l}\text { Standard } \\
\text { hiba }\end{array}$ & $\mathrm{p}$ \\
\hline $\begin{array}{l}\text { Mióta van az egészségügyi } \\
\text { pályán? }\end{array}$ & 2-5 év & 0,079 & 0,222 & 0,720 \\
\hline $\begin{array}{l}\text { Mióta van az egészségügyi } \\
\text { pályán? }\end{array}$ & 6-10 év & $-0,853$ & 0,253 & 0,0007 \\
\hline $\begin{array}{l}\text { Mióta van az egészségügyi } \\
\text { pályán? }\end{array}$ & $11-20$ év & 0,003 & 0,180 & 0,983 \\
\hline $\begin{array}{l}\text { Mióta van az egészségügyi } \\
\text { pályán? }\end{array}$ & 21 év felett & 0,868 & 0,176 & 0,000 \\
\hline $\begin{array}{l}\text { Rendelkezik saját } \\
\text { vállalkozással? }\end{array}$ & Nem & 0,133 & 0,113 & 0,240 \\
\hline Van hobbija? & Igen & 0,241 & 0,104 & 0,020 \\
\hline $\begin{array}{l}\text { Otthon vagy munkahelyen } \\
\text { kívüli baráti társaságban } \\
\text { meg tudja beszélni a } \\
\text { munkával kapcsolatos } \\
\text { érzéseit, élményeit? }\end{array}$ & Igen & 0,544 & 0,125 & 0,000 \\
\hline $\begin{array}{l}\text { Előfordulnak-e Önnél } \\
\text { jelenleg kisebb egészségi } \\
\text { problémák? }\end{array}$ & $\mathrm{Nem}$ & 0,710 & 0,095 & 0,000 \\
\hline
\end{tabular}

légkört, a hobbit, az egészségi probléma hiányát. Szignifikáns negatív eltérést azoknál találtunk, akik 6-10 éve dolgoznak, s kényszernek érzik jelenlegi helyzetüket (2. táblázat).

A teljesítménycsökkenésnél szignifikáns protektív tényezőnek bizonyult a saját vállalkozásnak, a sportnak a hiánya. Tehát minden olyan tényező, amely bármilyen pluszenergiát köthet le, csökkenti a teljesítményt (3. táblázat)
3. táblázat $\mid$ A teljesítmény csökkenését befolyásoló tényezők, szignifikáns eltérés a kiemelteknél

\begin{tabular}{lccll}
\hline Teljesítménycsökkenés & Válasz & Becslés & $\begin{array}{l}\text { Standard } \\
\text { hiba }\end{array}$ & $\mathrm{p}$ \\
\hline Rendelkezik saját vállalkozással? & Nem & 0,269 & 0,135 & 0,046 \\
Van hobbija? & Igen & 0,001 & 0,148 & 0,993 \\
$\begin{array}{l}\text { Otthon vagy munkahelyen } \\
\text { kívüli baráti társaságban meg } \\
\text { tudja beszélni a munkával } \\
\text { kapcsolatos érzéseit, élményeit? }\end{array}$ & Igen & $-0,477$ & 0,212 & 0,024 \\
$\begin{array}{l}\text { Előfordulnak-e Önnél jelenleg } \\
\text { kisebb egészségi problémák? }\end{array}$ & Nem & $-0,203$ & 0,121184 & 0,092 \\
$\begin{array}{l}\text { Sportol-e rendszeresen? } \\
\text { Nem }\end{array}$ & 0,272 & 0,122 & 0,026 \\
\hline
\end{tabular}

\section{Megbeszélés}

Az eredmények azért is meglepőek, mert hasonló tendenciákkal ugyan, de két dimenzióban (EE-, DP-átlagpontszám) is rosszabb eredményeket mutat a fogorvostársadalom, mint a 2013. évi nagy orvoskutatás [9]. Összehasonlítva a nagy orvoskutatás fogorvosokra irányuló adatgyüjtésével, elmondhatjuk, hogy a részvételi arány valamivel $(8 \%-\mathrm{kal})$ magasabb volt a mi vizsgálatunkban, valamint mind a három dimenzióban százalékosan többen (EE: 4,7\%-kal, DP: 2,2\%-kal, PA: 39,1\%kal) kerültek a magas kategóriába [10]. Más országok fogorvosaival összehasonlítva ezen eredményeket, elmondhatjuk, hogy egy indiai kutatásnál 4,5-szer roszszabb eredményeket regisztráltunk a teljesítménycsökkenés tekintetében [11], míg amerikai fogorvosok körében közel hasonló eredményeket regisztráltak minden dimenzióban [12]. Kétszer magasabb értékeket értünk el a DP és a PA tekintetében egy svájci fogorvosvizsgálathoz képest [13], valamint brazil szájsebészekhez hasonlóan a teljesítménycsökkenés területén mutattuk a legrosszabb adatokat [14]. A teljesítménycsökkenés ilyen magas arányában több tényezô együttes hatását valószínúsítjük: a fogorvosi munkára jellemző fizikai és emocionális megterhelést, a munkaidő rugalmatlanságát, hosszát, az adminisztrációs terhek folyamatos növekedését. A női fogorvosok számának növekedése a világon mindenütt jellemző [12], így az ezzel járó szerepkonfliktus is szerepet játszhat ezen eredményünkben, ami további vizsgálatotokat igényel. Egy koreai fogorvoskutatással összehasonlítva eredményeinket, elmondhatjuk, hogy szintén a fiatalabb korosztályban magasabb a kiégés valószínúsége: a PA tekintetében jobb eredményeket regisztráltak, a másik két dimenzióban kétszer magasabbakat. A munkakörnyezetet tekintve magasabb kiégést regisztráltak az olyan rendelőkben, ahol egyedül dolgoznak a praxisban - ebból is arra következtethetünk, milyen fontos a támogató munkahelyi környezet [15]. Török fogorvoskutatásban a férfiak körében szintén szignifikánsabb rosszabb eredményeket mértek a cinizmus terén, valamint a nők között az érzelmi kimerülés vonatkozásában [16]. Egy 
hongkongi fogorvoskutatás szerint a páciensek a legfontosabb stresszorok, azonban szignifikáns összefüggést találtak a foglalkozási stresszorok és a nagyfokú kiégés között is [17]. Más magyar kutatások szerint is az 1-2 éve dolgozók a leginkább érintettek [18], ami azt jelenti, hogy nagyobb figyelmet kell fordítani a fiatalabb kollégákra, hiszen ók a legveszélyeztetettebbek.

Nőket és férfiakat összehasonlító vizsgálatok szerint a női orvosok hajlamosabbak a depresszióra és a kiégésre, mint férfi kollégáik [12, 19]. Ebben döntő szerepe van annak a szerepkonfliktusnak, amely az orvosi és a családanyai szerep közötti összeütközésból ered, és a legjellemzőbben a gyermekszülés, gyermeknevelés időszaka alatt jelentkezik [20]. A mi eredményeinknél is látszik hasonló tendencia, de az eltérés nem volt szignifikáns.

Összefoglalva, eredményeink alapján elmondhatjuk, hogy a kiégés fokozottabban veszélyezteti a fogorvosokat Magyarországon, mint várható lenne a fenti irodalmi adatok alapján. A szükséges lépéseket mihamarabb meg kell kezdeni mind a prevenció, mind a terápia területén, hogy megoldjuk ezt a fontos problémát.

\section{A kiégésszindróma néhány prevenciós lehetősége}

Fontos a 'hivatásos segítő' foglalkozás választásának átgondolása, tudatosítása. Aki segítőpályát választ, az fokozott mértékü érzelmi kapcsolatot alakít ki a munkájából adódóan. A motivációját - egyedül vagy segítséggel - tudatosítania kell [21]. Német fogorvosok a pácienseikkel való találkozások 25\%-át találták kihívást jelentőnek. A kihívást jelentő betegek aránya szignifikánsan korrelált a kiégésteszten mutatott rossz eredményekkel, azaz minél több a nehezen kezelhető páciens, annál magasabb a kiégés valószínúsége [22].

A Semmelweis Egyetemen 2002-ben indult a HuMánia Pályaszocializációs Múhely, melynek célja az orvostanhallgatók kiégésének megelőzése.

Fontos a prevenció terén a munkával, hivatással kapcsolatban a saját személy fontosságának és jelentőségének érzése a munkahelyeken, valamint az autonómia, a szakmai fejlődés lehetősége, továbbá a támogatórendszerek - a munkahelyen stábmegbeszélések, esetmegbeszélés, szakmai továbbképzések, szupervízió, kollegiális konzultáció stb. - megléte, az anyagi-erkölcsi megbecsültség és a szakmai túlterheltség szabályozása [21].

További fontos lehetőségek például a reziliencia (lelki ellenálló képesség) növelése [23, 24], a 'mindfulness' (az éber figyelmen alapuló stresszcsökkentés) [25], a pszichológiai tanácsadás, a magasabb szintü önismeret [26] vagy a más országokban elterjedt 'sabbatical year', azaz a hat dolgos esztendőt követő hetedik évben teljes évi szabadság $[27,28]$.

Mint már említettük, a kiégésszindróma diagnózisa a legtöbbször öndiagnózis. A segítőszakmában időnként meg kell állni és megfogalmazni: milyen motiváció tart a pályán, és mit jelent számomra a segítés? Hogyan látnak engem a betegek, és hogyan a kollégák? A kiégés fenti szakaszaiban hol tartok? [21]

Anyagi támogatás: A közlemény megírása és a kapcsolódó kutatómunka anyagi támogatásban nem részesült.

Szerzôi munkamegosztás: Sz. E. és H. J.: A kutatás alapötlete, adatgyưjtés, irodalomkutatás. Sz. E.: A kézirat megírása, szerkesztése. K. P.: Statisztikai számítások. T. Zs.: A kutatás vezetője, részvétel a kézirat előkészítésében, javításában. A közlemény végleges változatát valamennyi szerző elolvasta, jóváhagyta.

Érdekeltségek: A szerzőknek nincsenek a közleménnyel összefüggő érdekeltségeik.

\section{Irodalom}

[1] Freudenberger JH. Staff burnout. J Soc Issues 1974; 30: 159165.

[2] Bordás A. Burnout syndrome in the foreign and domestic literature. [A kiégés-szindróma a külföldi és a hazai szakirodalomban.] Educatio 2010; 4: 666-672. [Hungarian]

[3] Pálfi I. The characteristics of nurses' and caregivers' behaviour in different clinical settings with special attention to burnout syndrome. Doctoral (PhD) thesis. University of Pecs, Faculty of Medicine, Institute of Behavioural Sciences, Pécs, 2007. [Ápolói és gondozói magatartások alakulása különböző ellátási helyzetekben, különös tekintettel a kiégés jelenségére. PhD-értekezés.] Pécsi Tudományegyetem, Általános Orvostudományi Kar, Pécs, 2007. [Hungarian]

[4] Yansane A, Tokede O, Walji M, et al. Burnout, engagement, and dental errors among U.S. dentists. J Patient Saf. 2020 Apr 3. doi: 10.1097/PTS.0000000000000673. [Epub ahead of print]

[5] Farkas A. Teacher burnout. The learner is an adult - the adult learner. [A tanári kiégés. A tanuló felnőtt - a felnőtt tanuló.] Országos Közoktatási Intézet, Szekcióülés, 2004. [Hungarian]

[6] Freudenberger H, North G. Burn-out in women. About the feeling of being burned out. [Burnout bei Frauen. Über das Gefühl des Ausgebranntseins.] Krüger, Frankfurt, 1992. [German]

[7] Maslach C, Jackson SE, Leiter MP. Maslach Burnout Inventory: Manual (3rd edition). Consulting Psychologists Press, Palo Alto, CA, 1996.

[8] Ádám Sz, Mészáros V. Psychometric properties and health correlates of the Hungarian version of the Maslach Burnout Inventory - Human Services Survey (MBI-HSS) among physicians. [A humán szolgáltató szektorban dolgozók kiégésének mérésére szolgáló Maslach Kiégés Leltár magyar változatának pszichometriai jellemzői és egészségügyi korrelátumai orvosok körében.] Mentálhig Pszichoszomat. 2012; 13: 127-143. [Hungarian]

[9] Györffy Zs, Girasek E, Nagy F. "Statistics tell about me..." The first results of the "Medical Research 2013” study. [ „Statisztikák mesélnek énrólam...” Az „Orvoskutatás 2013” vizsgálat első eredményei.] Orv Lapja 2013; 10: 5-7. [Hungarian]

[10] Győrffy Zs, Girasek E. Dentists: time balance, family, profession, health. [Fogorvosok: időmérleg, család, hivatás, egészség.] Magy Fogorv. 2014; 23(1): 36-40. [Hungarian]

[11] Khanna R, Khanna R. Is medicine turning into unhappy profession? Indian J Occup Environ Med. 2013; 17: 2-6. 
[12] Chohan L, Dewa CS, El-Badrawy W, et al. Occupational burnout and depression among paediatric dentists in the United States. Int J Pediatr Dent. 2020; 30: 570-577.

[13] Divaris K, Lai C, Polychronopoulou A, et al. Stress and burnout among Swiss dental residents. Schweiz Monatsschr Zahnmed. 2012; 122: 610-615.

[14] Porto GG, Carneiro SC, Vasconcelos BC, et al. Burnout syndrome in oral and maxillofacial surgeons: a critical analysis. Int J Oral Maxillofac Surg. 2014; 43: 894-899.

[15] Jin MU, Jeong SH, Kim EK, et al. Burnout and its related factors in Korean dentists. Int Dent J. 2015; 65: 22-31.

[16] Huri M, Bağış N, Eren H, et al. Association between burnout and depressive symptoms among Turkish dentists. J Dent Sci. 2016; 11: 353-359

[17] Choy HB, Wong MC. Occupational stress and burnout among Hong Kong dentists. Hong Kong Med J. 2017; 23: 480-488.

[18] Tandari-Kovács M. Emotional strain, mental burnout among healthcare workers. Doctoral dissertation. [Érzelmi megterhelődés, lelki kiégés az egészségügyi dolgozók körében. Doktori értekezés.] Semmelweis Egyetem, Mentális Egészségtudományok Doktori Iskola, Budapest, 2011. [Hungarian]

[19] Győrffy Zs, Ádám Sz. Development of health status, work stress and burnout in the medical profession. [Az egészségi állapot, a munkastressz és a kiégés alakulása az orvosi hivatásban.] Szociol Szle. 2004; 3: 107-127. [Hungarian]

[20] Győrffy Zs, Ádám Sz. Female role conflicts in the medical profession. [Szerepkonfliktusok az orvosnői hivatásban.] Lege Artis Med. 2003; 13: 159-164. [Hungarian]
[21] Ónody S. Genesis of burnout symptoms and possible solutions. [Kiégési tünetek (burnout szindróma) keletkezése és megoldási lehetőségei.] Új Pedagógiai Szle. 2001; 51: 80-85. [Hungarian]

[22] Goetz K, Schuldei R, Steinhäuser J. Working conditions, job satisfaction and challenging encounters in dentistry: a cross-sectional study. Int Dent J. 2019; 69: 44-49.

[23] Southwick SM, Charney DS. The science of resilience: implications for the prevention and treatment of depression. Science 2012; 338: 79-82.

[24] Győrffy Zs. Burnout and resilience among Hungarian physicians. [Kiégés és reziliencia (rugalmas ellenállás) a magyarországi orvosok körében.] Orv Hetil. 2019; 160: 112-119. [Hungarian]

[25] de Vibe M, Solhaug I, Tyssen R, et al. Mindfulness training for stress management: a randomised controlled study of medical and psychology students. BMC Med Educ. 2013; 13: 107.

[26] Czeglédi E, Tandari-Kovács M. Characteristics and prevention of burnout syndrome among nurses. [A kiégés előfordulása és megelőzési lehetőségei ápolók körében.] Orv Hetil. 2019; 160: 12-19. [Hungarian]

[27] Friedman SH. No worries, mate: a forensic psychiatry sabbatical in New Zealand. J Am Acad Psychiatry Law 2013; 41: 407-11.

[28] Sagmeister S. The power of time off. TEDGlobal 2009. Available from: http://www.ted.com/talks/stefan_sagmeister_the_ power_of_time_off [accessed : July 29, 2020].

(Szalai Eszter dr., Budapest, Szentkirályi u. 47., 1088 e-mail: szalai.eszter@dent.semmelweis-univ.hu)

\title{
Az Orvosi Hetilap 2021; 162: 239. oldalán (6. szám) megjelent OH-kvízre
} három helyes megfejtés érkezett.

\author{
A beküldők: Dr. Bíró László (Budapest), Dr. Kónya Csaba (Budapest) \\ és Dr. Somogyi Erzsébet (Budapest).
}

A nyerteseknek szívből gratulálunk.

Nyereményüket - egy, az Akadémiai Kiadó webáruházában kedvezményes vásárlásra jogosító kupont - e-mailen küldjük el.

A cikk a Creative Commons Attribution 4.0 International License (https://creativecommons.org/licenses/by/4.0/) feltételei szerint publikált Open Access közlemény, melynek szellemében a cikk bármilyen médiumban szabadon felhasználható, megosztható és újraközölhető, feltéve, hogy az eredeti szerző és a közlés helye, illetve a CC License linkje és az esetlegesen végrehajtott módosítások feltüntetésre kerülnek. (SID_1) 